\title{
CORPORATE SOCIAL RESPONSIBILITY AND PSYCHOLOGICAL CONTRACT: TOWARDS REDEFINING RELATIONSHIPS
}

REBECCA O. ENUOH

(Received 1 August 2017; Revision Accepted 1 November 2017)

\begin{abstract}
There is growing concern about the activities of business in society. Much attention is drawn to the changing nature of the relationship between corporations and society which has increased the demand for organisations to recognise their corporate social responsibility (CSR). This research explores an understanding of the relationship between multinational corporations and their host communities in the Niger Delta, Nigeria. Based on data from semi-structured interviews and focus group discussion in three host communities, there is an implicit contractual relationship which could be likened to that of a psychological contract. From a Psychological contract perspective, the study suggests the need for reciprocal benefits from both parties for desired positive impact. This study also establishes the nexus between CSR and psychological contract and contributes to evolving debates on CSR for improved relationships between business and the society.
\end{abstract}

KEYWORDS: Corporate social responsibilities, Psychological contract, Nigeria, Niger delta, relationship, Nigeria, Multinational corporations

\section{INTRODUCTION}

The relationship between business and society has evolved with time. Businesses have a duty towards their primary stakeholders (Carroll, 1999) just as they have towards the shareholders. Meeting societal expectations, which consequently leads to CSR initiatives has become a vital element in the success of corporations. This paper explores CSR in the context of the Nigerian oil industry with regards to corporate-community relations. In recent decades, the oil sector has experienced increasing pressure from the Nigerian government and the local people of this region due to the dependence of the Nigerian economy on crude oil which was discovered in 1956 (Evuleocha, 2005; Eweje, 2007; Idemudia \& Ite, 2006). The exploitation of commercial quantities of crude oil began in 1956 (Idemudia, 2010).
Nigeria produces approximately 2.3 million barrels of crude oil a day, and has an estimated oil reserves of 22.5 billion barrels mostly found in small fields in the coastal area of the Niger Delta region (Ajibade \& Awomuti, 2009). Most of the oil exploration and production activities take place in the Niger Delta region (NDR) consisting of nine of Nigeria's 36 states.

The NDR plays a significant role in the Nigerian economy because crude oil is the main source of the country's foreign exchange earnings and federal revenue (Evuleocha, 2005). Oil provides about $90 \%$ of Nigeria's foreign exchange earnings and $80 \%$ of annual federal revenue. Yet, in spite of the enormous earnings from the region's oil and gas deposits, it still remains the poorest in the country (Aaron, 2012). Petroleum profits have brought huge benefits to Nigeria as a whole, but very little to the local communities where the oil is being extracted

Rebecca O. Enuoh, Department of Business Management, University of Calabar, Calabar, Nigeria. 
(Evuleocha, 2005). Lack of development, widespread poverty, feeling of marginalization and discontent among the people of the Niger Delta have resulted in constant conflicts and crisis (Afinotan \& Ojakorotu, 2009).

There have been repeated agitations and sometimes violent acts by many host communities protesting against perceived suppression and denial of their rights to development. These tensions have affected not only the oil companies but the government as well. Instability in the region for the past two decades has severely disrupted the expansion of crude oil production and invariably revenue generation (Orogun, 2010). The discovery of oil in this region is often seen as good fortune to the Nigerian nation, but is also seen as having serious negative impact on the people of the NDR (Idemudia \& Ite, 2006). The inability of the Nigerian government to meet the needs of the oil producing communities has therefore increased the expectations from the oil multinationals for greater investment in CSR to improve their standard of living. The conflicts arise from the disagreements with the Federal Government over the ownership and control of oil resources as well as agitations with the oil companies over the benefits and negative impacts of oil extraction processes on their environment (Ako, 2012).

This research is pertinent in exploring how CSR can be used as an effective means of reducing the crisis in the $\operatorname{NDR}(A k o, 2012$; Idemudia, 2010) through socially acceptable business practices. This is borne from the assertion by Crane and Matten (2010) that business should contribute to solving social problems which may be caused by their activities (such as pollution) or some other causes. The research is also relevant in exploring how CSR undertaken by multinational oil companies can achieve desired positive impact (Ejumudo, Edo, Avweromre, \& Sagay, 2012)to enhance mutual understanding and peaceful coexistence between the host communities and the oil companies. It is one of the objectives of this paper to contribute to this area of study by providing guidance on what could constitute effective CSR. This research provides evidence to suggest that the perception of imbalances in the anticipated benefits from a relationship could negatively affect such a relationship

\section{The concept of Corporate Social Responsibility}

There is a growing body of literature that recognizes the importance of corporate social responsibility (CSR) in society (Griseri \& Seppala, 2010; Hopkins, 2006; Kim, Kim, \& Tam, 2016; Lea, 2002). CSR has become imperative for most businesses and organizations as it can contribute positively to economic, social and political development especially in developing countries (Ako, 2012). Despite the failure of scholars to provide a universally acceptable definition of the term (Dahlsrud, 2008; Wan Saiful, 2006) due to different explanations and interest, there is need for a contextual definition. Dahlsrud (2008) describes CSR as a phenomenon that is socially constructed which can only be understood by the way it is defined. However, recent developments in CSR tend to disregard the definitional problem but rather emphasize the need for corporations to focus on identifying the groups to which they must fulfil their responsibility, promote a good relationship with them and establish how to engage in more effective CSR (Kim et al., 2016).

In this paper therefore, CSR is viewed as the means by which a society's values and expectations are integrated into corporate behaviour(Griseri \& Seppala, 2010). In other words, corporations are expected to contribute to good society by improving the standard of living of the people through good business practices. Though there seems to be an agreement on the need for CSR, there is a great deal of debate as to what constitutes responsible behaviour and the limits of such responsibility. This research therefore focuses on the local communities' expectation of a firm to increase its positive impact and reduce its negative impact on the society in which it operates. Existing research recognize the role played by multinational oil companies in CSR initiatives in the Niger Delta region (Ite, 2007). Multinational Corporations (MNCs) have embarked on various projects aimed at reducing the suffering of people adversely affected by oil related activities and to create an enabling environment for their continuing business (Ejumudo et al., 2012). Tuodolo (2009) asserts that most of the services and infrastructure provided by some oil multinationals in the local communities in this 
region were either previously absent, insufficient or not functional. However, the processes of delivering CSR programmes by multinational oil companies indicate that the negative costs often outweigh the positive benefits CSR brings to local communities (Aaron, 2012; Tuodolo, 2009).

The negative impacts of oil spillages and gas flaring have adversely affected the people. Ako, Lawrence Ogechukwu, and Okonmah (2009) opine that incessant and repeated oil spillages within this region by oil companies has destroyed the farmlands and polluted the water/fish ponds of villagers living near those facilities and has also led to wildlife migration. These have contributed to the loss of traditional livelihoods and the means of survival of the local communities (Idemudia, 2009) who depended on them. The toll of oil exploitation activities on the people of the Niger delta suggests that the CSR undertaken by the oil corporations is not having the desired positive impact (Ejumudo et al., 2012) hence the cause of conflicts. Although the conflict issue in this region is multi-faceted, an understanding of the major causes is a significant step to finding a solution.

The central argument of this paper is that CSR could be a means of reducing the Niger Delta crisis if effectively implemented. However, the successful implementation of a CSR initiative largely depends on the involvement of the host communities from its initial planning to its execution stage which could also be referred to as stakeholder engagement as identified in Heravi, Coffey, and Trigunarsyah (2015). The stakeholder model(Donaldson, 1999; Fassin, 2009; Freeman, 1984; Manal El \& Cornet, 2012; Mitchell, Agle, \& Wood, 1997) is largely used to explain the relationship between the MNC and its host communities. Furthermore, this study lays emphasis on mutual benefit from corporate activities that hinge on ethical considerations of CSR initiatives rather than mere financial investment. Previous research has shown that traditional livelihoods have been lost due to oil exploitation as opined by Idemudia (2009). This paper therefore supports the need for more positive impacts of a firm's activities which is not only about "doing good" (Marom, 2006; Wood, 2010) as sometimes assumed, but doing what is right. However, constant protests by the host communities attest to their displeasure over the MNC's actions whose cost outweighs the benefits (Newell, 2005; Tuodolo, 2009), hence the demand for more benefits. This idea of mutual benefits could be likened to that of a psychological contract.

\section{Psychological Contract}

The psychological Contract $(\mathrm{PC})$ is an increasingly relevant aspect of workplace relationships and wider human behaviour (Raulapati, Vipparthi, \& Neti, 2010). It has become an accepted part of the vocabulary of human resource practitioners (Patrick, 2008). In defining the concept of the psychological contract, authors have used different terms; promises, expectations and obligations which suggest a degree of agreement between two parties though the level of assurance of fulfilment differs (Pate \& Scullion, 2010). Psychological contracts are individuals' beliefs regarding reciprocal obligations in a dual relationship between employees and organisations. It manifests itself in individuals' mental representations of their relationships with their organisations(Rousseau, 1998). The PC refers to the relationship between an employer and its employees and it is specifically concerned with mutual expectations of inputs and outcomes (Raulapati et al., 2010).

Psychological contract consists of unwritten agreements on direct or indirect promises, depending upon the way that individuals interpret them. For instance, an employee may expect to get money, job security, status, recognition, or the chance to be creative in return for hard work, consistency, commitment, or loyalty (Bellou, 2009). The level and kind of expectations, therefore, differ from one person to the other. It is an implicit contract between an individual and their organisation of expectations from and to each other in their relationship (Kotter, 1973). Psychological contract is an inherently substantive phenomenon because it is limited to the individual also because it could be modified based on multiple sources of information. While one individual believes in the existence of a particular PC, other members of the organisation or the supervisor, may not understand the contract from the same point of view (Rousseau, 1998). Psychological contracts by their nature are often implicit and not explicit, which makes it a complex issue (Guest, 1998). More broadly, psychological contracts are beliefs, based upon promises expressed or implied, regarding an exchange agreement between an individual and the organisations, the employing firm and its agents (Rousseau, 2004). 
From the definitions above, it can be deduced that there is a relationship, an unwritten agreement or an obligation which is subject to a wide range of interpretation. Considering the fact that the psychological contract is not written down, makes it quite complex because it may be difficult to meet the expectations of every employee of the organisation. This is so because different employees have their individual expectations which are devoid of uniformity. Since modern organisations cannot succeed without the contribution of their employees to their mission and survival, it is pertinent that workers and employers agree on their contributions and benefits from and to each other. Rousseau (2004)asserts that understanding and effectively managing these psychological contracts can help organisations thrive. When fair processes are utilized, employees are more satisfied with hiring, salaries and resource allocation and are more likely to exhibit positive behaviour. Employee trust in management and higher levels of job satisfaction is promoted by employers who understand and uphold the psychological contract (Niehoff \& Paul, 2001).

From the discussions above, the psychological contract has been considered from the perspective of individual to employer level of a reciprocal obligation/ expectation of each contribution towards the other party. In a psychological contract, it is the individual's unilateral belief in the reciprocity of the organisation to his or her contributions (O'Donohue \& Nelson, 2009). This couldbe considered as the micro-meso (individualcompany) level. However, this paper considers the concept of psychological contract from a perspective of the company to society (mesomacro) level. The concept of the psychological contract can be likened to the expectations by the host communities in the Niger Delta region of the multinational oil companies. The host communities in the study area expect drastic transformation of their environment, provision of jobs and the establishment of a cottage industry in return for their land that is being used for oil exploitation (Aghalino, 2009). The most important issue here is the fact that there is an expectation irrespective of its level. Unfortunately, because their expectations are not met, the oil companies in the area exist in constant opposition with the people.This couldbe likened to the dissatisfaction of an employee. The management of the oil companies are accused of enjoying good living conditions (which include availability of health care, good water supply, electricity, etc.), while the host communities have no access to such basic amenities, and a deplorable state of most of their communities completely enclosed in poverty (Okpo \& Eze, 2012).

The crisis in the NDR may not end so soon if the host communities perceive a breach of contract on the part of multinational oil companies. This is affirmed by Ibeanu (2000) who is of the view that the bulk of the oil revenue generated from this region should be returned to the region on the basis of fairness, compensation and self-determination. The attitude of the host communities towards the oil companies could be interpreted as being a result of a breach of contract by a company. Similarly, Niehoff and Paul (2001) assert that violation of a psychological contract can damage positive employee attitudes, reduce his citizenship behaviour and increase the likelihood of retaliation, sabotage, theft and other aggressive behaviours.

\section{CSR and the Psychological Contract}

The definitions of CSR and that of psychological contract above seem to have a common denominator which is 'obligation'. This obligation is due to an inherent relationship between the two parties, and the need for each party to live up to its expectations is inevitable and may attract grievous consequences. In a psychological contract, there are sets of beliefs about what each party is entitled to receive and obligated to give in exchange for the other party's contribution which is not explicitly made but perceived to exist in their eyes (Niehoff \& Paul, 2001). Psychological contracts have consistently been shown to impact on employee attitude and behaviour and to influence organisational effectiveness and efficiency. Fulfilment has shown positive impact while a breach has shown negative impact (Beynon, Heffernan, \& McDermott, 2012). Based on this assertion, the insurgency in the study area could be attributed to a perceived breach of theobligation of the oil companies by the host communities. Just as the obligation implicit in the psychological contract could affect the individual employee performance and subsequently that of the organisation, the obligation implicit in CSR could equally affect the attitude of the host communities and subsequently that of the oil companies. 
The host communities believe that they deserve a valued outcome in exchange for their land where oil is being exploited. The problems in the NDR, as earlier mentioned can also be attributed to environmental, political and socioeconomic factors which may be solved with effective CSR based on mutual understanding and sustainability. Idemudia and Ite (2006) conclude that the Niger Delta crisis can only be resolved through collective responsibility, the Nigerian government meeting its social responsibility, the oil multinationals addressing their CSR as well as reciprocal responsibility on the part of the host communities. Filling the gap in the literature, the research will therefore seek to understand if the concept of a psychological contract exists between the host communities and multinational oil companies in the NDR in order to reduce the crisis and unfriendly relationship between both parties. An understanding of the existence of the term will guide the way individuals assimilate, organise and make sense of the world around them and expose one to the complexity or ambiguity of the relationship.

\section{Methodology and Data}

An exploratory qualitative approach was used to understand and clarify the nature of the relationship between the multinational oil companies and the host communities in the Niger Delta region of Nigeria. The study also seeks to explore and understand the cause of frequent disputes between the parties involved. Data collection was by semi-structured interviews and focus groups. Face to face interviews were conducted with members of the host communities and employees of a multinational oil company (MNC). The study focused on three host communities as they were directly affected by the activities of the multinational oil company operating in that region. A total of 28 semistructured interviews were conducted, out of which 21 of the participants were from three host communities (Mkpanak, Eket and Edo communities). Three focus groups discussions were organised, two of the focus groups had five participants each while one of the focus groups had six participants. The participants of all the focus groups were members of the host communities. One of the focus groups was made up of youths only while the other two were a mix of youth, women and older men. They were carefully selected to provide a mix in terms of gender and age. The interesting aspect of the focus group was that one person's response triggered another person's recollection which was absent in individual interviews.

The interviews were conducted from midJune to October 2014. Identification and recruitment of appropriate participants was not an easy task because of the nature of the research which requires purposive sampling. We needed the right people to talk to especially those that were involved (directly or indirectly) in oil related issues in the region. Several attempts were made to contact some identified key people through emails and telephone calls as well as visits to the area of research which takes about 3-5 hours' drive (depending on traffic) due to a bad road. Most of the participants from the host communities were identified through a snowballing technique and contacts made. In situations where the contacts failed, efforts were made to get other suitable persons. At least a dozen trips were made to the study area because the study involves three host communities, the participants lived in different towns, and some appointments had to be cancelled and another date fixed for some of the interviews. Attempts were made to conduct more than one interview per day to reduce the cost of travelling, but some of the participants were not available on such dates which required more visits to the area. In line with the plan to speak with a variety of local inhabitants, we recruited elderly men, women, youth and youth leaders to participate in the research. The participants were selected based on their position in the community and/or their direct involvement in dealing with the MNC on behalf of their communities.

Table1.0 below shows a summary of the demographic information of the participants for semi-structured interviews with representatives of the host communities. The initials indicate coded name of participants. 
Table 1.0: Participants from 3 Host communities

\begin{tabular}{|l|l|l|l|l|l|}
\hline S/N & COMMUNITY & GENDER & $\begin{array}{l}\text { AGE } \\
\text { RANGE }\end{array}$ & $\begin{array}{l}\text { EDUCATIONAL } \\
\text { QUALIFICATION }\end{array}$ & OCCUPATION \\
\hline 1. & Mkpanak (PA) & Male & $60+$ & Master's degree & Lawyer \\
\hline 2. & Mkpanak (KA) & Male & $30-39$ & Bachelor degree & Employed \\
\hline 3. & Mkpanak (JE) & Female & $30-39$ & Bachelor degree & Self employed \\
\hline 4. & Mkpanak (EB) & Male & $40-49$ & Secondary school & Unemployed \\
\hline 5. & Mkpanak (MM) & Male & $50-59$ & Secondary school & Fisherman \\
\hline 6. & Mkpanak (FF) & Female & $50-59$ & Secondary school & Trader \\
\hline 7. & Mkpanak (GA) & Female & $60+$ & Bachelor degree & Self employed \\
\hline 8. & Mkpanak (ED) & Male & $20-29$ & Bachelor degree & Unemployed \\
\hline 9. & Eket (PE) & Male & $50-59$ & Doctoral degree & Public servant \\
\hline 10 & Eket (SE) & Male & $30-39$ & Bachelor degree & Youth activist \\
\hline 11. & Eket (FG) & Female & $40-49$ & Bachelor degree & Unemployed \\
\hline 12. & Eket (GO) & Female & $20-29$ & Undergraduate & Student \\
\hline 13. & Eket (RX) & Male & $20-29$ & Undergraduate & Student \\
\hline 14. & Eket (UJ) & Male & $30-39$ & Bachelor degree & Unemployed \\
\hline 15. & Eket (KO) & Female & $20-29$ & Undergraduate & Student \\
\hline 16. & Edo (HU) & Male & $40-49$ & Master's degree & Public servant \\
\hline 17. & Edo (MA) & Female & $50-59$ & Secondary school & Trader \\
\hline 18. & Edo (UD) & Female & $30-39$ & Bachelor degree & Unemployed \\
\hline 19. & Edo (DA) & Male & $40-49$ & Certificate of Education & Teaching \\
\hline 20. & Edo (BU) & Male & $30-39$ & Teacher's certificate & Teaching \\
\hline 21. & Edo (MN) & Male & $30-39$ & Bachelor degree & Civil servant \\
\hline
\end{tabular}

\section{RESULTS}

The findings from individual interviews as well as the focus groups indicate that there is mutual expectation which suggests possible reasons for the actions of the host communities towards the MNCs. In other words, there is an obligation of one from the other. The analysis so far suggests that there is a close interaction between the host communities, the MNC and the government. However, there seems to be a greater expectation from the MNC than the government. The analysis also reveals that the actions of the host communities towards the MNC indicate a perceived contractual relationship between them. Such expectations are based on what they believe is obtainable in other communities where oil is discovered and the need to be treated fairly as it applies to other oil communities. This is affirmed by the participant below who says;

'...our people feel the company has failed in its corporate social responsibility. The project they used to ehmm undertake are no more there so we are just named as a host community, but we are not getting what we are supposed to gain [...] they owe us the duty to meet our needs and nothing less. [...] even when a job opportunity comes they decide to do the interview and recruitment ahmm in Lagos and send the staff down. What they are doing is not fair at all. These have made the people not to have a cordial relationship with the company anymore, and it's giving us serious problems'.) SE, 23 sept, 2014, Eket)

Rather than benefit from oil exploitation by the MNCs, participants complain that their traditional livelihood activities such as farming and fishing have been negatively affected as shown in the statement from PA:

.. now we cannot do the fishing because of the oil operation, the incessant oil spills, killing the aquatic lives and so on[...] The people realize that the fishermen, farmers and others who depend on forest and sea products as means of livelihood are seriously damaged both the land and the sea has been polluted and the forest destroyed [..] They could not fish again because if there is oil spill [company] will try to 
bring chemical to spray on top and the chemical will make the oil in the form of ball, and they will sink into the bed of the sea.[..] If you are fortunate enough to get fish, you cannot get the taste again because of the oil'. (PA, 27 Oct, 2014, Mkpanak)

Similarly, some participants attributed the poor catch and infertility of the soil to oil extractive activities.

'The oil company's activities have negatively affected our means of livelihood so much. Am sure you must have heard about oil spillage and gas flaring. The oil spillage has affected our water and land such that we cannot catch as much fish as we used to do before and the soil is no longer fertile for our crops. Even the small vegetable gardens we used to have around our houses, when you plant the seed they refuse to germinate'. (BU, 15 Aug 2014, Edo)

This therefore suggest that oil spill is a major problem of the host communities which does not only affect their farmlands and the fishes in the water far from where they live but rather very close to their homes to the extent that the small gardens around their homes are also affected. However, this was disputed by a participant from the MNC operating in this region who stated that they operate off-shore and so it is not possible for the host communities to complain of the oil spill on their land. This claim is captured below:

\section{'all our warehouses are located in the sea, we don't operate on land, you will not see any of our pipelines crossing anybody's water, anybody's land, anybody's farmland that is why you've not heard of oil spill [...]' (AS, $4^{\text {th }}$ Aug 2014).}

It is, therefore, difficult to determine whose story to believe; whether that of the host communities or that of the MNC. The host communities are complaining on one hand of the oil that spills on their land, whereas the MNC is saying that they do not spill oil as all their facilities are off-shore. The above statement gives one the impression that the MNCs are more concerned about protecting their interest rather than solving the problem. Saying that the company's facilities are off-shore does not mean that oil spill does not occur. This statement places the company on the defence and as such indirectly freeing themselves from the blame for the oil spill. This may look like a good report for the company, but it does not in any way solve the problem. As a major multinational oil company in the state, there is a limit to what can be said to exonerate them from blame. The common concern is that oil spill occurs in this region irrespective of the facilities from which the oil spills.

The attitude of the MNC above suggest that there is an unhealthy relationship between the host communities and the company which has contributed to the conflicts and negative relationship. This could also be attributed to misunderstanding in handling the role each group should play to enhance mutual benefits. The relationship is that of anticipated valued outcome from the MNC in exchange for the oil extracted from their land. Though the host communities have not denied that the MNC have contributed to the economic growth of their region in some way, they also feel that such contributions cannot be compared to the negative effect of oil extractive processed on their livelihoods.

\section{DISCUSSION}

A psychological contract is a conceptual representation of the relationship between an employer and its employees with regard to a reciprocal obligation (Rousseau, 2004). The fundamental idea in such a contract $(P C)$ is the expectation of valued outcome in exchange for something, even if all the expectations may not necessarily be met at stipulated times. Just as a $P C$ is perceived in the mind of the employee towards his or her employer, findings from this study show that a similar view is held by the host communities towards the MNCs. The host communities expect to benefit from the MNC through the provision of a better standard of living, good infrastructural facilities, job opportunities and more money in their pockets by oil exploitation on their land. On the other hand, the MNC expect a cooperative attitude from the host communities and a conducive operational environment in exchange for their CSR initiatives. These mutual expectations of input and output are similar to that of a PC (Raulapati et al., 2010). While the host communities are 
complaining that they are not benefiting as much as they ought to from the oil companies, the MNCs also expect a more positive attitude from the host communities and that they should be commended for their efforts. This further explains the relationships that exist between the two groups. It is argued in Niehoff and Paul (2001) that the violation of a psychological contract can damage employees' positive attitude which could result in aggressive behaviour and sabotage. PC is exemplified in the action of the host communities whose constant conflict with the MNC is attributed to a breach of contract. This kind of relationship of expecting mutual benefit occurs in a psychological contract which does not seem to be fully operational. This therefore represents what could be called "Communal PC" in this specific context. Unlike the original conceptual description of PC, where mutual benefit is expected between an individual (employee) and his/her employer, the communal PC considers mutual expectation of a larger group (community) from the MNC.

Another important concept that was explored in understanding the relationship between the host communities and the MNC was that of responsibility. The respondents seem to use responsibility to mean the same thing as CSR. Responsibility specifically connotes a moral obligation to behave correctly towards or in respect of something. Such obligation is not limited to any particular person or group of people. While some participants used the term "responsibility" specifically, others used words/ phrases like "ought to", "duty", "have to" and "should" to describe what they considered an act of responsibility (CSR) of the MNCs towards them. Members of the host communities expect the MNCs to employ their youths, provide good water, good roads, build schools and pay compensation for the destruction of their land and water and lots more (Ako et al., 2009).

themselves as having any reciprocal responsibility towards the MNCs. Their attitude of blocking the roads, the airstrip and the entrance to the MNC's administrative office is perceived as a reaction to what they consider "irresponsible behaviour" of the MNCs rather than an act of irresponsibility on their part. Considering their status as stakeholders which are described in Freeman and Evan (1990) as those who benefit from the corporation or are harmed by its actions and whose rights may be violated or respected by corporate action, the host communities feel that the MNCs have an obligation towards them. Hence, the MNCs take oil from their land and so they should give something useful back to the community in the form of exercising their social responsibility (Eweje, 2007).

On the other hand, the MNCs expect the host communities to be more responsible in their attitude. The findings show that the MNCs have made considerable efforts to meet the needs of the host communities through various CSR initiatives. Though some have been acknowledged, others have been criticised. The argument here is that responsibility should be considered as reciprocal and thereby similar to the notion contained within the concept of a PC. The issue of responsibility, therefore, dominates any discussion on CSR because it is part of the definition. Whether the responsibility involves the society or an individual, what readily comes to mind is a responsibility to whom? Or being responsible for something (Votaw, 1973). Responsibility cannot be established without a relationship. Hence a relationship must exist for responsibility to exist. In the case of the Niger Delta, the MNCs have a relationship with the host communities due to constant daily interactions as they operate within the communities. This relationship is what Idemudia (2010) refers to as corporate-community relations which make organisations responsible to communities. Such responsibilities are expected to be mutual as both parties have their different roles to play in order to foster a good relationship. In a situation where one party perceives the other as not being responsible, the relationship is bound to be unfriendly (Ako et al., 2009) because it will be perceived as a breach of promise (whether implicit or explicit).

Bowen (1953) may be right to interpret corporate responsibility in the light of philanthropy in the sense that most CSR initiatives are voluntary. But most of the people in the NDR do not subscribe to such notional limits of corporate responsibility. For those in the host communities, such interpretations of CSR do not apply to them because they consider the CSR initiatives an obligation that must be fulfilled. On the other hand, Davis (1960) and Frederick (1960) dismissed the philanthropic approach to CSR. This is in contrast to the attitude of the MNC is due to the conviction amongst the host communities that since the company is exploiting oil from their land, it owes them something in 
return as a matter of responsibility. There is, therefore, a fundamental difference in the premise of the argument of the company and that of the host communities. While on one hand the company believes that it should decide how much and in what form to give out what it considers as philanthropic gifts to the communities, the communities believe that they deserve more from the company because what is being offered to them already belongs to them. So, communities see what companies give as their 'rights' and what is due to them rather than a kindly philanthropic gesture on behalf of benevolent companies above and beyond their obligations.

This explains why any attempt to use CSR as a strategic solution to the crisis will amount to operating on the wrong premise. Under such circumstances, CSR will rarely achieve its desired positive impact. For the majority, CSR may not be legally binding, but it is a moral and social requirement for any company operating in the NDR. It gives the company, not only the obligation to provide infrastructure, but also the social license to operate. Schwartz and Carroll (2003) assert that organisations have a responsibility towards each stakeholder which consists of economic, ethical and legal responsibilities and which they identify as being the concern of both primary and secondary stakeholders. These domains of the approach to CSR are also identified as the concerns of the host communities in this research. The host communities desire economic gain from the MNC, legal commitment to live up to their expectations as well as demanding ethical consideration in their practices in order to reduce the negative impact of oil exploitation on their environment. The argument here is that CSR should be considered from a PC perspective based on a reciprocal relationship and mutual expectations. The way an employee anticipates valued outcome in exchange for his/her skills, knowledge, hard work, dedication or service to the employer as contained in a PC, is the same way the host communities feel towards the MNC. The host communities anticipate valued outcome in the form of providing basic social amenities, job creation and a better standard of living from the MNC in exchange for their land on which oil is being exploited. It is argued that understanding CSR from a PC perspective would improve the relationship between the MNC and their host communities.

\section{CONCLUSION}

This study makes several contributions to the current literature and adds substantially to improve our understanding of CSR. The host communities consider CSR from the view point of obligation/ perceptions /expectations from the MNC as regards fair treatment, improving their quality of life and reducing the negative impact of oil extractive processes. This is believed to be part of the bargain in their relationship with the MNC. The argument is that meeting such expectations would reinforce commitment on the part of the host communities and a cordial relationship which could also contribute to the survival of the firm. It is also established that the expectations are closely linked to the views of the host communities as stakeholders to the MNC. Therefore, as local communities hold a stake in the company, neglecting their interest could negatively affect the performance of the firm. It could also be said that accommodating the interests of the stakeholders is important in achieving a mutually beneficial outcome.

The host communities expect a lot from the MNC, and the same is expected of the host communities in return by the MNCs. This implies that a reciprocal obligation is expected of each group of the other. The relationship between the firm and its local stakeholders is, therefore, that of mutual expectation which could be met through CSR. The locals think it is unfair for oil to be drilled from their land and revenue therefrom used to develop other parts of the country while the resource area remains underdeveloped. They also feel unfairly treated by the MNC by not providing employment and other job opportunities for the younger generation. Based on their perceived stakeholder relationship with the MNC, their confrontational attitude emphasises the need for mutual benefits. However, the MNC think they have done enough already through CSR initiatives and that the locals are unfair and unreasonable in their actions. The MNC expect the host communities to appreciate their efforts and reciprocate their gesture through cooperation with them rather than being hostile. The relationship between both parties would best be understood and redefined from a psychological contract perspective.

\section{Direction for future research}

Based on the findings of the study, future research should involve multiple case studies. 
The study was carried out in one of the major oilproducing states in the Niger Delta region. There are other areas in the region where similar investigation could be done to understand the host communities' relationship with the MNC, especially in areas more prone to conflicts. Similarly, research could be undertaken to accommodate more multinational companies of varying sizes operating within the country. Such studies could likewise be carried out with indigenous oil companies to compare the outcomes. Most research on CSR in developing countries is focused on the oil industry; itis suggested that further studies be carried out in other sectors of the economy.

\section{ACKNOWLEDGEMENT}

This paper was first presented at the $7^{\text {th }}$ International Conference on "Restructuring of the Global Economy", held at Said Business School, University of Oxford, United Kingdom on 3-4 $4^{\text {th }}$ July, 2017. The conference was organised by Academy of Business and Retail Management (ABRM). The submission is therefore modified based on the input from conference participants.

\section{REFERENCES}

Aaron, K. K., 2012. New corporate social responsibility models for oil companies in Nigeria's delta region: What challenges for sustainability? Progress in Development Studies, 12, (4): 259-273. doi:http://dx.doi.org/10.1177/1464993412 01200401

Afinotan, L and Ojakorotu, V., 2009. The Niger Delta crisis: Issues, challenges and prospects. African journal of political science and international relations, 3, (5): 191-198.

Aghalino, S., 2009. Corporate response to environmental deterioration in the oil bearing area of the Niger Delta, Nigeria, 1984-2000. Journal of sustainable development in Africa, 11,(2): 281-294.

Ajibade, L and Awomuti, A., 2009. Petroleum exploitation or human exploitation? An overview of Niger Delta oil producing communities in Nigeria. African Research Review, 3, (1): 111-124.
Ako, R., 2012. Re-defining corporate social responsibility (CSR) in Nigeria's postamnesty oil industry. African Journal of Economic and Management Studies, 3, (1): 9-22. doi:http://dx.doi.org/10.1108/2040070121 1197258

Ako, R., Lawrence Ogechukwu, O and Okonmah, P., 2009. Forging peaceful relationships between oil-companies and host-communities in Nigeria's Delta region. Journal of Enterprising Communities, 3, (2): 205216. doi:http://dx.doi.org/10.1108/175062 00910960888

Bellou, V., 2009. Profiling the desirable psychological contract for different groups of employees: evidence from Greece. The International Journal of Human Resource Management, 20, (4): 810-830. doi:10.1080/095851909027707 11

Beynon, M. J., Heffernan, M and McDermott, A. M., 2012. Psychological contract and job satisfaction: clustering analysis using evidential C-means and comparison with other techniques. Intelligent Systems in Accounting, Finance \& Management, 19, (4): 247-273. doi:10.1002/isaf.1334

Bowen, H. R., 1953. Social responsibility of the businessman. New York: Harper and Row.

Carroll, A. B., 1999. Corporate social responsibility. Business and Society, 38, (3): 268-295.

Crane, A and Matten, D., 2010. Business Ethics; Managing corporate citizenship and sustainability in the age of globalization. New York: Oxford University Press.

Dahlsrud, A., 2008. How corporate social responsibility is defined: an analysis of 37 definitions. Corporate Social Responsibility \& Environmental Management, $\quad 15, \quad(1)$ : $1-13$. doi:10.1002/csr.132

Davis, K., 1960. Can Business Afford to Ignore Social Responsibilities? California Management Review, 2, (3): 70-76. 
Donaldson, T., 1999. Response: Making Stakeholder Theory Whole. The Academy of Management Review, 24, (2): 237-241. doi:10.2307/259079

Ejumudo, K., Edo, Z., Avweromre, L and Sagay, J., 2012. Environmental issues and corporate social responsibility(CSR) in Nigeria Niger Delta region: the need for a pragmatic approach. Journal of Social Science and Public Policy, 4, 1-21.

Evuleocha, S. U., 2005. Managing indigenous relations: Corporate social responsibility and corporate communication in a new age of activism. Corporate Communications: An International Journal, 10, (4): 328-340.

Eweje, G., 2007. Multinational oil companies' CSR initiatives in Nigeria. Managerial Law, $\quad 49, \quad(5 / 6)$ : $218-235$. doi:http://dx.doi.org/10.1108/0309055071 0841340

Fassin, Y., 2009. The Stakeholder Model Refined. Journal of Business Ethics, 84, (1): 113-135. doi:http://dx.doi.org/10.1007/s10551-0089677-4

Frederick, W. C., 1960. The Growing Concern Over Business Responsibility. California Management Review, 2, (4): 54-61.

Freeman, R. E., 1984. Strategic Management: A stakeholder Approach. Boston: Pitman Publishing.

Freeman, R. E and Evan, W. M., 1990. Corporate governance: A stakeholder interpretation. Journal of Behavioral Economics, 19, (4): 337.

Griseri, P and Seppala, N., 2010. Business Ethics and Corporate Social Responsibility. London: Cengage Learning.

Guest, D. E., 1998. Is the psychological contract worth taking seriously? Journal of Organizational Behavior, 19, (7): 649664.

Heravi, A., Coffey, V and Trigunarsyah, B., 2015. Evaluating the level of stakeholder involvement during the project planning processes of building projects.
International Journal of Project Management, $\quad 33, \quad(5)$ : 985-997. doi:http://dx.doi.org/10.1016/j.jproman.2

014.12.007

Hopkins, M., 2006. What is Corporate Social Responsibility all About? Journal of Public Affairs (14723891), 6(3/4), 298306. doi:10.1002/pa.238

Ibeanu, O., 2000. Understanding and effectively managing these psychological contract can help organizations thrive. African Association of Political Science, 2, (6): 163-167.

Idemudia, U., 2009. Oil Extraction and Poverty Reduction in the Niger Delta: A Critical Examination of Partnership Initiatives. Journal of Business Ethics, 90, 91-116. doi:http://dx.doi.org/10.1007/s10551-0089916-8

Idemudia, U., 2010. Rethinking the role of corporate social responsibility in the Nigerian oil conflict: The limits of CSR. Journal of International Development, 22, (7): 833-845.

Idemudia, U and Ite, U. E., 2006. Demystifying the Niger Delta conflict: Towards an integrated explanation. Review of African Political Economy, 33, (109): 391.

Ite, U. E., 2007. Partnering with the state for sustainable development: Shell's experience in the Niger Delta, Nigeria. Sustainable Development, 15, (4): 216.

Kim, S., Kim, J. N and Tam, L., 2016. Think socially but act publicly: refocusing CSR as corporate public responsibility. Journal of Public Affairs (14723891), 16, (1): 91104. doi:10.1002/pa.1560

Kotter, J. P., 1973. The Psychological Contract: Managing the Joining-Up Process. California Management Review, 15(3), 91-99.

Lea, R., 2002. Corporate Social responsibility. Retrieved from http://www.epolitix.com/data/companies/i mages/companies/Institute-of Direcors/CSR_Report.pdf [23 June 2003]. website: 
Manal El, A and Cornet, A., 2012. Towards a Dynamic Stakeholder Management framework for CSR Certifications. International Journal of Business and Social Science, 3(4).

Marom, I. Y., 2006. Toward a Unified Theory of the CSP-CFP Link. Journal of Business Ethics, $\quad 67, \quad$ (2): 191-200. doi:10.2307/25123864

Mitchell, R. K., Agle, B. R and Wood, D. J., 1997. Toward a Theory of Stakeholder Identification and Salience: Defining the Principle of Who and What Really Counts. The Academy of Management Review, 22, (4): $\quad$ 853-886. doi:10.2307/259247

Newell, P., 2005. Citizenship, accountability and community: the limits of the CSR agenda. International Affairs, 81(3), 541-557. doi:10.1111/j.1468-2346.2005.00468.x

Niehoff, B. P and Paul, R. J., 2001. The Just Workplace: Developing and Maintaining Effective Psychological Contracts. Review of Business, 22(1/2), 5.

O'Donohue, W and Nelson, L., 2009. The Role of Ethical Values in an Expanded Psychological Contract. Journal of Business Ethics, 90, (2): 251-263. doi:10.1007/s10551-009-0040-1

Okpo, O and Eze, R., 2012. Vandalization of oil pipelines in the Niger Delta region of Nigeria and poverty: an overview. Studies in Sociology of Science, 3, (2): 13-21.

Orogun, P. S., 2010. Resource control, revenue allocation and petroleum politics in Nigeria: the Niger Delta question. GeoJournal, $\quad 75, \quad$ (5): 459-507. doi:http://dx.doi.org/10.1007/s10708-0099320-7

Pate, J and Scullion, H., 2010. The changing nature of the traditional expatriate psychological contract. Employee Relations, $\quad 32, \quad(1)$ : $\quad 56-73$. doi:10.1108/01425451011002761

Patrick, H. A., 2008. Psychological Contract and Employment Relationship. ICFAI Journal of Organizational Behavior, 7, (4): 7-24.
Raulapati, M., Vipparthi, M and Neti, S., 2010. Managing Psychological Contract. IUP Journal of Soft Skills, 4, (4): 7-16.

Rousseau, D. M., 1998. The 'problem' of the psychological contract considered. Journal of Organizational Behavior, 19, (7): 665-671.

Rousseau, D. M., 2004. Psychological Contracts in the Workplace: Understanding the Ties That Motivate. Academy of Management Executive, 18, (1): 120-127. doi:10.5465/AME.2004.12689213

Schwartz, M. S and Carroll, A. B., 2003. Corporate social responsibility: A threedomain approach. Business Ethics Quarterly, 13, (4): 503-530.

Tuodolo, F., 2009. Corporate Social Responsibility: between civil society and the oil industry in the developing world. An International E-journal for critical geographies, 8, (3): 530-541.

Votaw, D., 1973. Genius Becomes Rare: A Comment on the Doctrine of Social Responsibility Pt. II. California Management Review, 15, (3): 5-19.

Wan Saiful, W. J., 2006. Defining corporate social responsibility. Journal of Public Affairs (14723891), 6, (3/4): 176-184. doi:10.1002/pa.227

Wood, D. J., 2010. Measuring Corporate Social Performance: A Review. International Journal of Management Reviews, 12, (1): 50-84. doi:10.1111/j.1468- 